\title{
Effect of Rearing Systems on Growth Performance and Carcass Characteristics of Desi Chicken
}

\author{
Abhale Manoj Bhimraj ${ }^{1}$, Dukare Sagar Popat ${ }^{3}$, O.P. Dinani ${ }^{3 *}$, \\ M. Babu', Asha Rajani ${ }^{1}$ and Pram Valli ${ }^{2}$ \\ ${ }^{1}$ Division of Poultry Science, ${ }^{2}$ Division of Animal Nutrition, Madras Veterinary collage, \\ TANUVAS, Chennai-600007, India \\ ${ }^{3}$ ICAR-Central Avian Research Institute, Izatnagar, Bareilly, U.P-243122, India \\ *Corresponding author
}

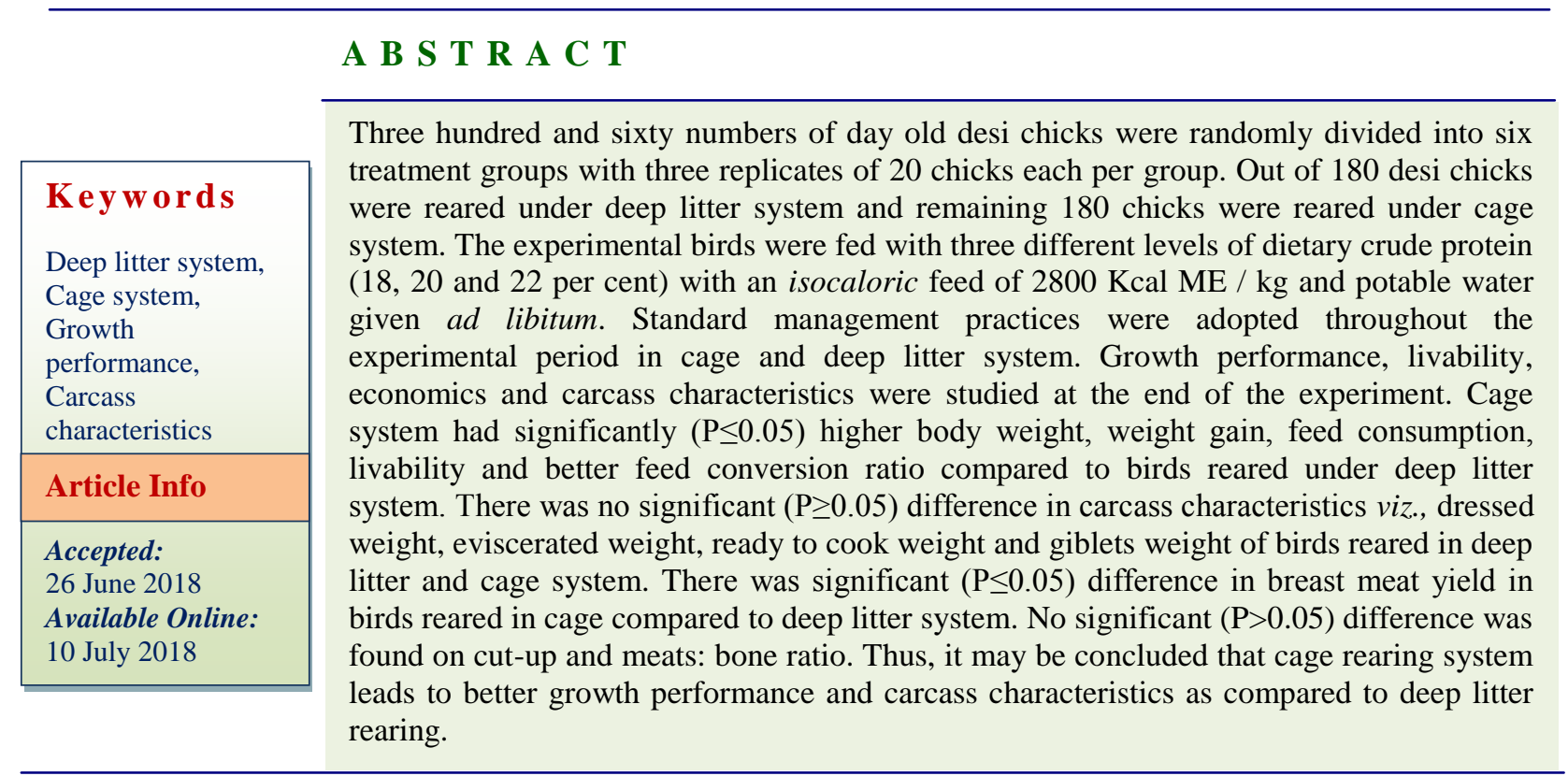

\section{Introduction}

Indigenous chicken breeds of India are of importance due to their unique attributes like hardiness and tropical adaptability. India has more than 20 recognized indigenous poultry breeds and preference for indigenous chicken meat over commercial broiler is due to its characteristic flavor (Vij et al., 2006). Market demand for commercial chicken is relatively high, but the supply is rather limited. Farmers before the advent of commercial native chicken were not interested in systematic production and no particular feeding and housing standards for native chicken was followed. However, there is a growing 
domestic market for native chicken in retail outlets with consumers willing to pay premium price for native chicken meat (Choprakarn et al., 2000). Backyard chicken rearing is an old tradition in India. Among 70 per cent population living in rural areas and 89 per cent of rural livestock holders rear poultry as an important supplementary income source (Khandait et al., 2011). In India, Aseel is one of the important native breed that is being reared in its native tract Andhra Pradesh for game and meat purposes. Aseel is recognized for its high stamina, majestic gait, disease tolerance and adaptability to adverse climatic conditions (Singh. 2009).This bird is the base for the population of commercial native chicken. These chickens are being reared under intensive system, usually up to 12 weeks of age. Aseel chicken are slow grower (Haunshi et al., 2011) hence, the practice of providing them with standard chick starter (broiler/layer) diet is neither economical nor suitable to achieve optimum growth performance. Previous studies with indigenous chicken of China had demonstrated that nutrient requirement of native breeds were different compared to those of commercial layer or broiler (Zhao et al., 2009). Also it has been reported that slow growing birds need lesser dietary crude protein for optimum performance. In view of escalation of feed price, efficient utilization of feed for optimum production of native chicken is an essential prerequisite. Therefore it is felt necessary to know the precise nutrient requirements of these germplasm for intensive system of production.

\section{Materials and Methods}

Chicks were divided into six treatments with three replicates of 20 birds in each i.e., 60 birds in each treatment. First three treatments were reared in cages and remaining three on deep litter. Experiment was designed to study the effect of three different levels of dietary crude protein 18, 20 and 22 per cent with an isocaloric diet containing $2800 \mathrm{kcal} / \mathrm{kg} \mathrm{ME}$ on growth performance, all the experimental birds were wing banded and maintained under standard management conditions on deep litter and cages. Birds were fed ad libitum with known quantity of feed. Clean potable water was provided ad libitum (Table 1).

\section{Body weight and weight gain}

Body weight of birds were recorded every two weeks of age up to 14 weeks in the morning before feeding by using electronic weighing balance.

\section{Feed consumption and feed efficiency}

Birds were provided with ad libitum experimental feed (known weight) during the experimental period and at the end of each week, the left over feed was weighed back and net feed consumption was arrived, for each treatment. Feed efficiency was calculated biweekly up to 14 weeks of age.

\section{Livability}

Mortality among birds were recorded on its occurrence during the experimental period. The wing band number was noted and post mortem done to identify the cause of mortality.

\section{Carcass characteristics}

At the end of fourteen weeks of age i.e. experimental period 4 birds (two male+ two female) from each replicate were randomly selected for carcass characteristic study. Parameters viz., live weight, dressed weight, eviscerated weight, giblet weight and ready-to cook weight, cut up parts viz., breast, back, thigh, drumstick, neck, and wing were weighed and recorded. The meat was separated from bone and weighed separately to obtain meat: bone ratio. 


\section{Statistical analysis}

All the data collected from the experiment were subjected to statistical analysis as per Snedecor and Cochran, (1994) to find out statistical significance between treatments in each rearing system software SPSS version 16.0 .

\section{Results and Discussion}

\section{Body weight and weight gain}

Effect of rearing system on body and weight body weight gain was shown in Table 2 . The results showed significantly $(\mathrm{P}<0.05)$ higher body weight in birds from 4 week to 14 week of age. At 2 weeks of age no significant $(\mathrm{P}>0.05)$ difference were observed between cages and deep litter reared birds. However, from 4 to 14 week of age, birds reared in cage grown with significantly $(\mathrm{P}<0.05)$ higher body weight than deep litter reared birds. The results showed significant $(\mathrm{P} \leq 0.05)$ difference in cumulative body weight gain in birds from 6 to 14 week of age. Cage reared bird performed well compared to deep litter reared. There was no significant $(\mathrm{P}>0.05)$ difference in cumulative body weight gain at two and four week of age. A clear distinctive and significant $(\mathrm{P} \leq 0.05)$ difference in body weight gain (BWG) was observed between birds reared in cages and deep litter from 6 to 14 week of age, with birds reared in cages showing significantly $(\mathrm{P} \leq 0.05) \quad$ increased BWG. Cage reared desi chicken attained higher body weight at 14 week of age than deep litter system in this study is comparable with the results obtained by Gondwe and Wollny (2005) who compared growth performance of local chicken in cage and deep litter system. Numerous literature reviewed have shown that researchers tested local or native chicken performance have compared different systems of rearing like Magala et al., (2012) reared local chicken under free range, semi-intensive and deep litter system; Doley et al., (2009) in North eastern Himalayan chicken and Chatterjee et al., (2002) compared deep litter and backyard. However, one researcher Gondwe and Wollny (2005) compared cage and deep litter system.

\section{Feed consumption and feed conversion ratio}

Effect of rearing system on feed consumption and FCR were shown in Table 3. The results indicated that the feed consumption was significantly $(\mathrm{P} \leq 0.05)$ higher in birds reared in cages than deep litter system. Up to $2^{\text {nd }}$ week age, desi birds in deep litter consumed significantly $(\mathrm{P}<0.05)$ more feed than birds in cage system. However cage reared desi chicken consumed significantly $(\mathrm{P} \leq 0.05)$ more feed than birds reared in deep litter from 4 to 14 week of age. The feed conversion ratio recorded in desi chicken reared in cage and deep litter system was statistically similar at 2 week to 14 week of age in this study. Though feed consumption was higher in cage system, feed conversion ratio was significantly improved at 10 and 12 week of age only, not up to 14 week of age. Desi chicken reared in cage consumed significantly $(\mathrm{P} \leq 0.05)$ more feed than reared in deep litter from 4 to 14 week of age in this study. The difference was more as the age advanced. Gupta et al., (2000) reported feed consumption of Aseel chicken reared under deep litter at $1^{\text {st }}, 2^{\text {nd }}, 3^{\text {rd }}$ month i.e. $4^{\text {th }}, 8^{\text {th }}$ and $12^{\text {th }}$ week of age as 124,300 and $540 \mathrm{~g}$ respectively, which were higher (361.42 g, $1249.76 \mathrm{~g}$ and $2657.24 \mathrm{~g}$ ) in this study. Magala et al., (2012b) reared local chicken in deep litter, fed with 18 per cent protein and $2800 \mathrm{Kcal} \mathrm{ME} / \mathrm{kg}$ consumed 5.5 $\mathrm{kg}$ of feed up to 16 week of age whereas up to 14 week of age desi chicken fed 18 per cent protein, reared in deep litter consumed $3542 \mathrm{~g}$ feed in this study. Jha and Prasad (2012) reported lesser feed consumption in hybrid chicken variety than Aseel reared in deep 
litter. Satheeskumar et al., (2012) reported average feed consumption of native chicken up to 93 days as $4.41,4.33,4.25 \mathrm{~kg}$ in small, medium and large farm respectively. Birds reared in this study in terms of marketing age (93 days vs 98 days) consumed $3542 \mathrm{~g}$ in deep litter system.

\section{Livability}

Effect of rearing system on livability was shown in Table 3 . The occurrence of mortality in both the system of rearing was random and throughout the experimental period of 0 to 14 week of age. At the end of experiment the livability was higher in cage system than deep litter. Rearing system might not have influenced on livability and on occurrence of mortality in this study. Desi chicken reared up to 14 week of age registered 90 per cent livability in cage system and 87.78 per cent in deep litter system in this study is almost in accordance with Jha and Prasad (2012) who reported 90.15 per cent livability in Aseel, 96.28 per cent livability in Kadaknath and 91.72 per cent livability in Hazra. Kalitha et al., (2011) reported highest mortality of 17.83 per cent in indigenous chicken of Assam under deep litter system up to 5 week of age, whereas the mortality in desi chicken up to 4 or 6 week of age was 2.22 per cent in cage system and in deep litter it was 2.77 per cent.

Table.1 Ingredient and nutrient composition of basal diet used during Pre-starter, Starter,

\section{Finisher ration}

\begin{tabular}{|l|l|l|l|}
\hline Ingredients $(\mathrm{Kg} / 100 \mathrm{~kg})$ & Pre-starter & Starter & Finisher \\
\hline Maize & 45.00 & 45.00 & 45.00 \\
\hline Bajra & 22.50 & 16.00 & 12.60 \\
\hline Wheat bran & 8.00 & 8.00 & 6.00 \\
\hline Soya & 15.63 & 22.13 & 27.53 \\
\hline Fish meal & 7.00 & 7.00 & 7.00 \\
\hline Mineral Mixture* & 1.50 & 1.50 & 1.50 \\
\hline Feed Additives** & 0.37 & 0.37 & 0.37 \\
\hline Crude protein & 18.30 & 20.27 & 22.12 \\
\hline Energy(Kcal ME/kg) & 2800 & 2800 & 2800 \\
\hline Crude fiber & 3.40 & 3.63 & 3.68 \\
\hline Cost per kg (Rs) & 22.50 & 24.00 & 25.50 \\
\hline$*$ Mineral mixture & & $* *$ Feed additives & \\
\hline Ingredients & $\%$ & Ingredients & $\%$ \\
\hline Dicalcium phosphate & 51.38 & AB2D3K & 0.01 \\
\hline Calcite & 46.72 & Tefroli & 0.05 \\
\hline Iron sulphate & 0.94 & Ultracil & 0.02 \\
\hline Iron sulphate & 1.23 & UltraB12 & 0.01 \\
\hline Zinc oxide & 0.50 & Perivac & 0.02 \\
\hline Potassium iodide & 0.017 & Larvadox & 0.10 \\
\hline & & Ultravit M & 0.10 \\
\hline & & NaCl & 0.01 \\
\hline
\end{tabular}


Table.2 Effect of rearing system on body and weight body weight gain

\begin{tabular}{|c|c|c|c|c|}
\hline Age in weeks & \multicolumn{2}{|c|}{ Body weight } & \multicolumn{2}{c|}{ Body Weight Gain } \\
\hline & Cage & Deep litter & Cage & Deep litter \\
\hline 0 day & $31.89 \pm 0.23$ & $31.35 \pm 0.24$ & - & - \\
\hline 2 week & $70.63 \pm 0.90$ & $72.52 \pm 0.92$ & $38.72 \pm 1.40^{\text {NS }}$ & $41.17 \pm 1.47^{\text {NS }}$ \\
\hline 4 week & $162.92^{\mathrm{a}} \pm 2.34$ & $152.73^{\mathrm{b}} \pm 2.10$ & $128.23 \pm 4.56^{\mathrm{NS}}$ & $121.22 \pm 3.36^{\mathrm{NS}}$ \\
\hline 6 week $^{*}$ & $309.93^{\mathrm{a}} \pm 4.32$ & $267.02^{\mathrm{b}} \pm 3.96$ & $278.02^{\mathrm{a}} \pm 7.13$ & $233.65^{\mathrm{b}} \pm 7.13$ \\
\hline 8 week $^{*}$ & $470.02^{\mathrm{a}} \pm 6.75$ & $434.98^{\mathrm{b}} \pm 7.33$ & $438.18^{\mathrm{a}} \pm 10.60$ & $403.81^{\mathrm{b}} \pm 12.17$ \\
\hline $\mathbf{1 0}^{\mathrm{b}}$ week $^{*}$ & $756.92^{\mathrm{a}} \pm 9.77$ & $665.28^{\mathrm{b}} \pm 10.30$ & $720.71^{\mathrm{a}} \pm 18.07$ & $633.99^{\mathrm{b}} \pm 17.78$ \\
\hline $\mathbf{1 2}^{\text {week }^{*}}$ & $1033.07^{\mathrm{a}} \pm 12.58$ & $946.13^{\mathrm{b}} \pm 13.39$ & $994.81^{\mathrm{a}} \pm 23.76$ & $914.71^{\mathrm{b}} \pm 22.97$ \\
\hline $\mathbf{1 4}^{*}$ week $^{*}$ & $1248.71^{\mathrm{a}} \pm 15.61$ & $1182.48^{\mathrm{b}} \pm 16.73$ & $1202.11^{\mathrm{a}} \pm 31.58$ & $1151.11^{\mathrm{b}} \pm 28.82$ \\
\hline
\end{tabular}

Table.3 Effect of rearing system on feed consumption, FCR and Livability

\begin{tabular}{|c|c|c|c|c|c|c|}
\hline \multirow[t]{2}{*}{ Age in weeks } & \multicolumn{2}{|l|}{ Feed consumption } & \multicolumn{2}{|l|}{ FCR } & \multicolumn{2}{|c|}{ Livability } \\
\hline & Cage & Deep litter & Cage & Deep litter & Cage & Deep litter \\
\hline 2 week $^{\text {NS }}$ & $136.22^{\mathrm{a}} \pm 2.77$ & $142.78^{b} \pm 0.58$ & $3.59 \pm 0.21$ & $3.57 \pm 0.19$ & 99.75 & 100.00 \\
\hline 4 week * & $378.46^{\mathrm{a}} \pm 1.22$ & $361.42^{b} \pm 0.97$ & $2.91 \pm 0.10$ & $3.01 \pm 0.09$ & 97.78 & 97.23 \\
\hline 6 week* & $739.71^{\mathrm{a}} \pm 1.77$ & $701.62^{b} \pm 1.10$ & $2.69^{\mathrm{a}} \pm 0.08$ & $3.01^{b} \pm 0.09$ & 96.67 & 94.45 \\
\hline 8 week* & $1303.77^{\mathrm{a}} \pm 2.39$ & $1249.76^{b} \pm 1.81$ & $3.00 \pm 0.10$ & $3.13 \pm 0.11$ & 95.00 & 92.80 \\
\hline 10 week* & $1989.54^{\mathrm{a}} \pm 2.99$ & $1892.12^{\mathrm{b}} \pm 2.89$ & $2.71^{\mathrm{a}} \pm 0.06$ & $2.94^{b} \pm 0.04$ & 95.00 & 91.70 \\
\hline 12 week* & $2787.15^{\mathrm{a}} \pm 3.96$ & $2657.24^{b} \pm 3.86$ & $2.79^{\mathrm{a}} \pm 0.04$ & $2.91^{b} \pm 0.04$ & 92.80 & 90.00 \\
\hline 14 week* & $3715.18^{\mathrm{a}} \pm 4.27$ & $3542.02^{\mathrm{b}} \pm 4.98$ & $3.06 \pm 0.04$ & $3.09 \pm 0.04$ & 90.00 & 87.78 \\
\hline
\end{tabular}

Table.4 Effect of rearing system on carcass characteristics, cut up parts and meat/bone ratio in native chicken

\begin{tabular}{|c|c|c|}
\hline & \multicolumn{2}{|c|}{ Rearing system } \\
\hline & Cage & Deep litter \\
\hline \multicolumn{3}{|l|}{ Carcass characteristics (\%) } \\
\hline Dressed weight & $90.80 \pm 0.86^{\mathrm{NS}}$ & $90.74 \pm 1.06^{\mathrm{NS}}$ \\
\hline Eviscerated weight & $71.47 \pm 1.08^{\mathrm{NS}}$ & $70.58 \pm 1.26^{\mathrm{NS}}$ \\
\hline Ready- to-cook weight & $76.27 \pm 1.05^{\mathrm{NS}}$ & $75.66 \pm 1.21^{\mathrm{NS}}$ \\
\hline Giblet weight & $6.13 \pm 0.35^{\mathrm{NS}}$ & $6.68 \pm 0.36^{\mathrm{NS}}$ \\
\hline \multicolumn{3}{|l|}{ Cut up parts (\%) } \\
\hline Breast * & $24.23^{\mathrm{a}} \pm 0.59$ & $22.92^{b} \pm 0.68$ \\
\hline Back & $19.69 \pm 0.34^{\mathrm{NS}}$ & $19.42 \pm 0.71^{\mathrm{NS}}$ \\
\hline Thighs & $16.58 \pm 0.70^{\mathrm{NS}}$ & $15.79 \pm 0.58^{\mathrm{NS}}$ \\
\hline Drumsticks & $16.40 \pm 0.60^{\mathrm{NS}}$ & $15.56 \pm 0.46^{\mathrm{NS}}$ \\
\hline Wings & $12.12 \pm 0.67^{\mathrm{NS}}$ & $12.81 \pm 0.53^{\mathrm{NS}}$ \\
\hline Neck & $6.16 \pm 0.56^{\mathrm{NS}}$ & $5.80 \pm 0.61^{\mathrm{NS}}$ \\
\hline \multicolumn{3}{|l|}{ Meat/Bone ratio } \\
\hline Meat & $51.66 \pm 0.42^{\mathrm{NS}}$ & $51.55 \pm 0.59^{\mathrm{NS}}$ \\
\hline Bone & $42.00 \pm 0.37^{\mathrm{NS}}$ & $41.67 \pm 0.56^{\mathrm{NS}}$ \\
\hline Meat/Bone ratio & $1.23 \pm 0.016^{\mathrm{NS}}$ & $1.24 \pm 0.03^{\mathrm{NS}}$ \\
\hline
\end{tabular}




\section{Carcass characteristics}

Effect of rearing system on carcass characteristics in native chicken was shown in Table 4. The carcass characteristics recorded in 14 week old desi chicken reared in cage and deep litter has not shown any significant $(\mathrm{P}>0.05)$ difference in this study. Similar results were obtained by Lariviere et al., (2009) at 85 days of age of chicken. Indigenous chicken of North Eastern region of India reared in deep litter registered 68.13 per cent dressing yield by Doley et al., (2009) which is lower than 75.66 per cent recorded in this study. Mondal et al., (2004) recorded 77.57 and 80.77 per cent dressing percentage in Aseel crosses at 12 week of age whereas in this study the dressing percentage of desi chicken were 75.66 and 76.27 per cent in deep litter and cage at 14 week of age.

\section{Cut up parts}

Effect of rearing system on cut up parts in native chicken was shown in Table 4 . The cut up parts of desi chicken at 14 week of age produced significantly $(\mathrm{P} \leq 0.05)$ heavier breast in cage system than deep litter. Other cut up parts viz., back, thighs, drumsticks, wings and neck in cage and deep litter system did not show any significant $(\mathrm{P}>0.05)$ difference in this study. Cage reared desi chicken at 14 week of age produced significantly $(\mathrm{P} \leq 0.05)$ heavier breast meat than deep litter and this was supported by Kgwatalala et al., (2013) who recorded significantly $(\mathrm{P}<0.05)$ heavier breast in Naked neck chicken at 20 week of age. Other cut up parts yield viz., back, thighs, drumsticks, wings and neck of desi chicken reared in cage or deep litter system, fed varying dietary protein level did not show significant $(\mathrm{P}>0.05)$ difference in these cut up parts reported by Kgwatalala et al., (2013). Magala et al., (2012a) also reported significantly higher breast yield (24.0 per cent) in local chicken reared in deep litter, the yield is 22.92 per cent in this study. Rajkumar et al., (2011) obtained significantly higher giblets yield (4.74 per cent) in Naked neck than normal chicken, which is lower than 6.10 to 6.88 per cent giblets yield recorded in this study. Lariviere et al., (2009) reported higher breast yield of 18 per cent in naked neck chicken at 11 week of age, while it was 22.92 to 24.33 in this study in deep litter and cage system. In Naked neck chicken, Paul et al., (1990) recorded 3.5 per cent more breast yield than broiler chicken reared in deep litter system.

\section{Meat: bone ratio}

Effect of rearing system on meat: bone ratio in native chicken was shown in Table 4. There was no significant $(\mathrm{P}>0.05)$ difference between meat, bone and meat: bone ratio in different rearing system. Ganbadi et al., (2009) reported meat: bone ratio of hind quarter of indigenous chicken and broiler chicken as 3.4 and 2.9. Wall and Anthony (1995) found no significant ( $\mathrm{P}>0.05)$ difference between the total breast mass of the deshi chicken and broilers, but reported that the deshi chicken had less breast muscle when deboned.

In conclusion, cage system had significantly $(\mathrm{P} \leq 0.05)$ higher body weight, weight gain, feed consumption, livability and better feed conversion ratio compared to birds reared under deep litter system. There was no significant $(\mathrm{P} \geq 0.05)$ difference in carcass characteristics viz., dressed weight, eviscerated weight, ready to cook weight and giblets weight of birds reared in deep litter and cage system. There was significant $(\mathrm{P} \leq 0.05)$ difference in breast meat yield in birds reared in cage compared to deep litter system. No significant $(\mathrm{P}>0.05)$ difference was found on cut-up and meats: bone ratio. Thus, it may be concluded that cage rearing system leads to better growth performance 
and carcass characteristics as compared to deep litter rearing.

\section{References}

Vij, P.K., M. S.Tantia and R.K. Vijh, 2006. Characterisation of Punjab brown chicken. Animal Genetic Resource Information, 39:65-76.

Choprakarn, K., V. Watanakul, K. Wongsvichet and V. Suriyachantrathong, 2000. Native and crossbreed chicken: Past and future. National Research Funding and Supporting Office, Bangkok, Thailand.

Khandait, V. N., S.H.Gawande, A.C. Lohakare and S.A. Dhenge, 2011. Adoption level and constrains in backyard poultry rearing practices in Bhandara district of Maharashtra (India). Research J. agri. Sci., 2(1): 110-113.

Singh Mohan, (1999). Production and other characteristics of Aseel peela desi male under intensive system. Indian J. Poult. Sci., 43(2): 217-219.

Haunshi Santosh, 2011. Performance of native chickens of Mizoram under intensive system of rearing. The Indian veterinary journal., 88(3): 4547.

Zhao J.P., J.L. Chen, G.P. Zhao, M.Q. Zheng, R.R. Jiang and J. Wen, 2009. Live performance, carcass composition and blood metabolite responses to dietary nutrient density in two distinct broiler breeds of male chicken. Poult. Sci., 88 (12): 2575-2584.

Snedecor, G.W and W. G. Cochran, 1994. Statisticak methods. The Iowa state University press, $8^{\text {th }}$ Edition, Ames, Iowa. U.S.A

Gondwe, T.N. and C.B.A. Wollny (2005) Evaluation of the growth potential of local chickens in Malawi.
International Journal of Poultry Science., 4(2): $\mathrm{xx}-\mathrm{xx}$.

Magala, H., 2008. Effect of management system on the performance of growing chicken cockerels. A special project report submitted to faculty of agriculture Makerere University, Kampala Uganda. pp 25-34.

Doley Santosh, 2010. Effect of rearing systems on meat and egg qualities in indigenous fowls. The Indian veterinary journal., 87: 168-170.

Chatterjee, R. N., S.P.S Ahlawat, S.P.Yadav, S. Senani, A. Kundu, S. Jeyakumar, S.K. Saha, Jai sunder and Deepa Bharti, 2002. Studied comparative growth performance of Nicobari fowl and their cost effectiveness under backyard and intensive system. Indian J. Poult. Sci., 37(1): 63-66.

Magala, H., D.R. Kugonza, H. Kwizera and C.C Kyarisiima, 2012b. Studied the influence of varying dietary energy and protein on growth and carcass characteristics of Ugandan local chickens. J Anim Adv., 2(7): 316-324.

Jha and Prasad, 2012. Production performance of improved varieties and indigenous breed of chicken in Jharkhand. Indian J. Poult Sci., 48(1): 109-112.

Satheeskumar, S., R. Prabakaran, N. Kumaravelu, S. Ezhilvalavan and A. Serma Saranava Pandian, 2012. Housing and feeding practices in intensive rearing of native chicken in Western Tamil Nadu. The Indian veterinary journal., 90(7): 47-49.

Kalitha, N., N. Pathak and R. Islam, 2011. Studied the performance of indigenous chicken in intensive system of management. The Indian vet. j. 89 (12): 43-44.

Doley, S., N. Barua, N. Kalitha and J.J. Gupta, 2009. Studied performance of indigeneous chicken of North Eastern 
region of India under different rearing system. Indian J. Poult. Sci., 44(2): 249-252.

Mondal, A., M. Patel, A. Kumar, B. Singh, A.K. Ghosh, R.K. Bhardwaj, 2007. Performance of different crossbreed chickens in intensive system. Indian $J$. Poultry Sci., 42: 211-214.

Kgwatalala, P.M., A. M. Bolowe, K. Thutwa and S. J. Nsoso, 2013. Carcass traits of the naked-neck, dwarf and normal strains of indigenous Tswana chickens under an intensive management system. Agric. Biol. J. N. Am., 4(4): 413-418.

Magala, H., D.R. Kugonza, H. Kwizera and C.C Kyarisiima, 2012a. Studied the influence of management system on growth and carcass characteristics of Ugandan local chickens. J Anim Adv., 2(6): 558-567.

Rajkumar, U., M. R. Reddy, S. V. Rama Rao, K. Radhika and M. Shanmugam, 2011. Evaluation of growth, carcass, immune response and stress parameters in naked neck chicken and their normal siblings under tropical winter and summer temperatures. Asian-Aust. J. Anim. Sci., 24(4): 509 516.

Lariviere, J.M., F. Farnis, J. Detilleux, C. Michaux, V. Verleyen and P. Leroy, 2009. Performance, breast morphological and carcass traits in the Ardennaise chicken breed. International journal of poultry science., 8(5): 452-456.

Paul, D. C., M. A. Beg, E. R. Chowdhary and podder, 1990. Comparison of meat yield between free range desi and broiler chicken. Indian Journal of Animal Sciences., 60(7): 866-868.

Ganbadi, S., S. Mutuviren, M.A. Hilmi, S.M.A. Babji, H. Yaakub and S. Fakurazi, 2009. Carcass composition of jungle fowl in comparison with broiler and indigenous chicken. Asian J. Vet. Sci., 3(1): 13-17.

Wall, C.W., N.B. Anthony, 1995. Inheritance of carcass variables when Giant jungle fowl and broilers achieve a common physiological body mass. Poultry Sci., 74: 231-236.

\section{How to cite this article:}

Abhale Manoj Bhimraj, Dukare Sagar Popat, O.P. Dinani, M. Babu, Asha Rajani and Pram Valli. 2018. Effect of Rearing Systems on Growth Performance and Carcass Characteristics of Desi Chicken. Int.J.Curr.Microbiol.App.Sci. 7(07): 3517-3524. doi: https://doi.org/10.20546/ijcmas.2018.707.408 